Research Article

\title{
The Use of Fish Flour and Palm Sugar Medium to Grow Mataram Indigenous Isolate of Entomopathogenic Bacillus thuringiensis for Controlling Aedes agypti Larvae
}

\author{
Bambang Fajar Suryadi *, Hilal Aisyah Hidayat, Galuh Tresnani \\ Department of Biology, Faculty of Mathematics and Natural Sciences, University of Mataram, Mataram 83125, \\ Indonesia
}

Article history:

Submission March 2019

Revised March 2019

Accepted April 2019

*Corresponding author:

E-mail: bambangfajar@unram.ac.id

\begin{abstract}
To grow Mataram indigenous local isolate of entomopathonic Bacillus thuringiensis using 4 combinations of fish flour and palm sugar natural liquid medium. The culture was then tested against 3rd instar Aedes aegypti larvae to gain lethal concentration (LC) value within 72-hour test. Four combinations of fish flour and palm sugar liquid medium (in $1: 1 ; 1: 3 ; 1: 5$ and $1: 7$ weight ratio) were made to grow $B$. thuringiensis isolate Bt-TP2B. Cell, endospore and protein crystal were recorded every 24 hours within 72-hour incubation. Seventy-two-hour-old B. thuringiensis cultures from those media were serially diluted, then tested against 3rd instar B. thuringiensis larvae. Larval death was recorded every 24 hours within 72-hour observation to obtain lethal concentration (LC) values. Results from all medium were compared to those of NYSM standar medium. B. thuringiensis isolate BT-TP2B could grow in fish flour and palm sugar natural medium. The highest toxicity (the lowest LC) was seen on B. thuringiensis grown on fish flour and palm sugar natural medium in 1:1 weight ratio. The LC50 values were 1.98x103 cell/mL (in 24-hour observation) and $1.49 \times 103$ cell $/ \mathrm{mL}$ (in 48-hour and 72 -hour observation), while LC90 values were $1.35 \times 103$ cell $/ \mathrm{mL}$ in 24 -hour observation and $1.58 \times 103 \mathrm{cell} / \mathrm{mL}$ in 48 and 72 -hour observations). These values were lower (more toxic) compared to those of NYSM standard medium. Fish flour and palm sugar natural medium could be used to grow entomopathogenic $B$. thuringiensis. Moreover, this natural medium could increase toxicity of $B$. thuringiensis against B. thuringiensis 3rd instar larvae.
\end{abstract}

Keywords: Bacillus thuringiensis, Aedes aegypti, fish flour, palm sugar, toxicity

\section{Introduction}

Dengue Haemorrhagic Fever (and some other infectious disease) is still becoming health problem in Mataram, Indonesia. Statistic shows 1,605 people are suffering from the the disease [1]. DHF is caused by Dengue Virus (Flavivirus) and spread among people by Aedes aegypti mosquito [2]. $B$. thuringiensis control can be achieved in many ways, however many studies recommend integrated mosquito managements to deal with the problem [3]. One component of this integrated approach is by controlling $B$. thuringiensis larvae either with chemical agent or biological agent. The most popular biological used is $B$. thuringiensis, a soil bacterium widely spread throughout the world. The ability of the bacterium to kill mosquito larvae caused by some toxin protein exist in their cell (i.e.-endotoxins) [4].

Up to recent time, bio-pesticide products based on B. thuringiensis in Mataram/Indonesia market are still imported from other countries. This situation hampers mosquito control program that's making it inefficient. To reduce dependence against importing such products, it is important to encourage research in exploring local $B$. thuringiensis isolates and local material to grow the bac-

\section{How to cite:}

Suryadi BF, Hidayat HA, Tresnani G (2019) The Use of Fish Flour and Palm Sugar Medium to Grow Mataram Indigenous Isolate of Entomopathogenic Bacillus thuringiensis for Controling Aedes agypti Larvae. Journal of Tropical Life Science 9 (2): 155 - 161. doi: 10.11594/jtls.09.02.04 
teria.

Fish (including its byproduct) and palm sugar are some of many local commodities of Mataram [5]. Fish flour (fishmeal) is made from remaining/unused fish widely abundant in surrounding waters. Palm sugar is well known as cooking sugar in this place and its tree is widely spread throughout Mataram as well. These two materials have potential to be utilized for growing $B$. thuringiensis. Fish flour can be used as nitrogen source, while palm sugar can be used as carbon source to fulfill the bacteria needs during its growth. Therefore, the aims of this study were to obtain the best combination fish flour and palm sugar (four combinations were applied) which resulting the highest toxicity of $B$. thuringiensis against $B$. thuringiensis 3rd-instar larvae.

\section{Material and Methods}

\section{B. thuringiensis isolate and B. thuringiensis lar- vae preparation}

In this study, we used $B$. thuringiensis isolate BT-TP2B generously provided by Ms. Herfianti from her study [6]. B. thuringiensis stock culture was refreshed on Nutrient Agar solid medium supplemented with $30 \mu \mathrm{g} / \mathrm{mL}$ Penicillin and incubated on $350 \mathrm{C}$ for 24 hours [7]. When growth is observed, Gram, endospore and crystal characteristic observation was made to ensure there was not any contamination in culture. B. thuringiensis larva was reared in Medical Research Unit - West Nusa Tenggara General Hospital. The larva used in this study was 3rd-instar larvae which obtained from 6-7 days rearing procedure.

\section{Natural medium and B. thuringiensis production}

Natural fermentation medium used were localproduced fish flour (as nitrogen source) and palm sugar (as carbon source). Both materials were purchased at local market on Mataram City.

The medium in fermentation process were made in four combination based on component ratios. The combinations were $1: 1$ (i.e. 1-part fish flour: 1-part palm sugar); $1: 3 ; 1: 5$ and $1: 7$. The based concentration was $50 \mathrm{~g} / \mathrm{L}$ medium.

The medium was made by mixing fish flour, palm sugar and aquadest (in accordance to the component ratio combination). The mix was heated to boil for 3 minutes and let it sit to the room temperature. Standard medium used was
NYSM liquid medium as described by El-Bendary [8].

One full loop of $B$. thuringiensis isolate TP2B from NA solid culture was added to four natural tested medium combination and NYSM control medium. Fermentation was conducted on $350 \mathrm{C}$ with rigorous shaking for 72 hours. Measurement on cell, endospore and crystal concentration were done every 24 hours. All measurements were made using Naubauer counting chamber in three replications.

\section{Bioassay}

Bioassay was performed to obtain Lethal Concentration (LC) value. The procedure was done as described by McLaughlin et al. [9]. Four natural media tested in 10-fold concentration differences and control medium were prepared. One thousand five hundred 3rd-instar $B$. thuringiensis larvae were distributed evenly to 75 containers (20 larvae per container). Mortality of larvae was recorded every 24 hours for 72 hours. LC values were calculated using Probit Analysis [10] applying MINITAB V16 Statistical Software for Windows [11].

\section{Results and Discussion Cell concentration}

Comparison of cell concentration among $B$. thuringiensis cultured in 4 combinations of fish flour - palm sugar medium within 72-hour incubation was presented in Figure 1.

The highest cell concentration reached by $B$. thuringiensis grown in fish flour - palm sugar natural medium was from $1: 5$ ratio medium (6.50 $\times$ $10^{7}$ cell $/ \mathrm{mL}$ ), followed by $1: 3$ ratio, $1: 7$ ratio and 1:1 ratio. B. thuringiensis grown in NYSM standard medium showed the highest cell concentration $\left(7.00 \times 10^{7} \mathrm{cell} / \mathrm{mL}\right)$ from all medium, whereas the lowest concentration was reached by $B$. thuringiensis grown in fish flour - palm sugar natural medium in $1: 1$ ratio $\left(1.20 \times 10^{5} \mathrm{cell} / \mathrm{mL}\right)$. In this observation, NYSM standard medium could give the highest $B$. thuringiensis cell concentration in the first 24 hours then decreased rapidly after 48hour incubation.

All B. thuringiensis cultured in 4 combinations (1: 1 to $1: 7$ ratios) of fish flour - palm sugar natural medium and NYSM standard medium showed significantly different cell concentration $(\mathrm{F}=$ 4495.01, $\mathrm{p}<0.05)$. B. thuringiensis cultures 


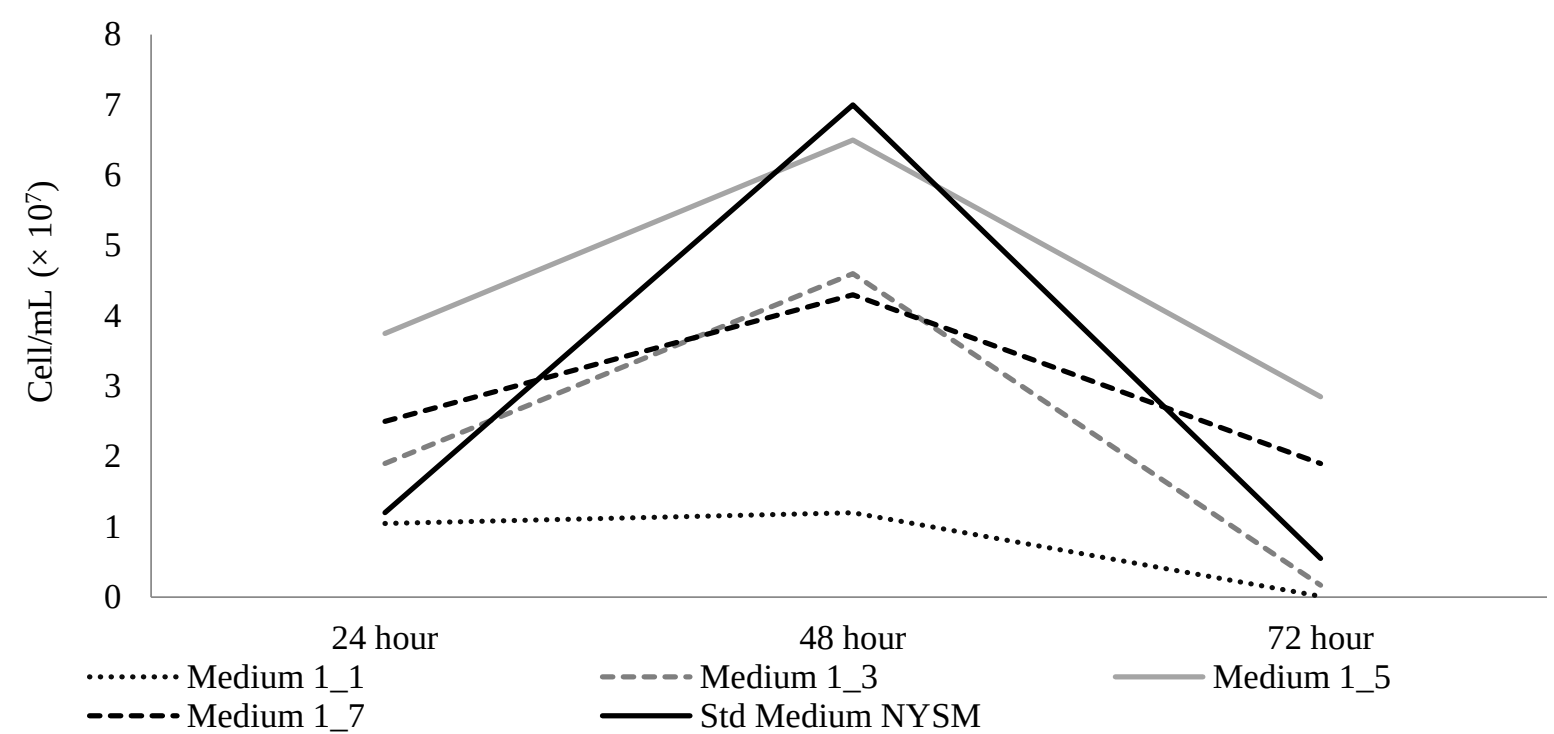

Figure 1. Comparison of cell concentration among B. thuringiensis grown in 4 combinations of fish flour -palm sugar medium and NYSM standard medium within 72-hour incubation

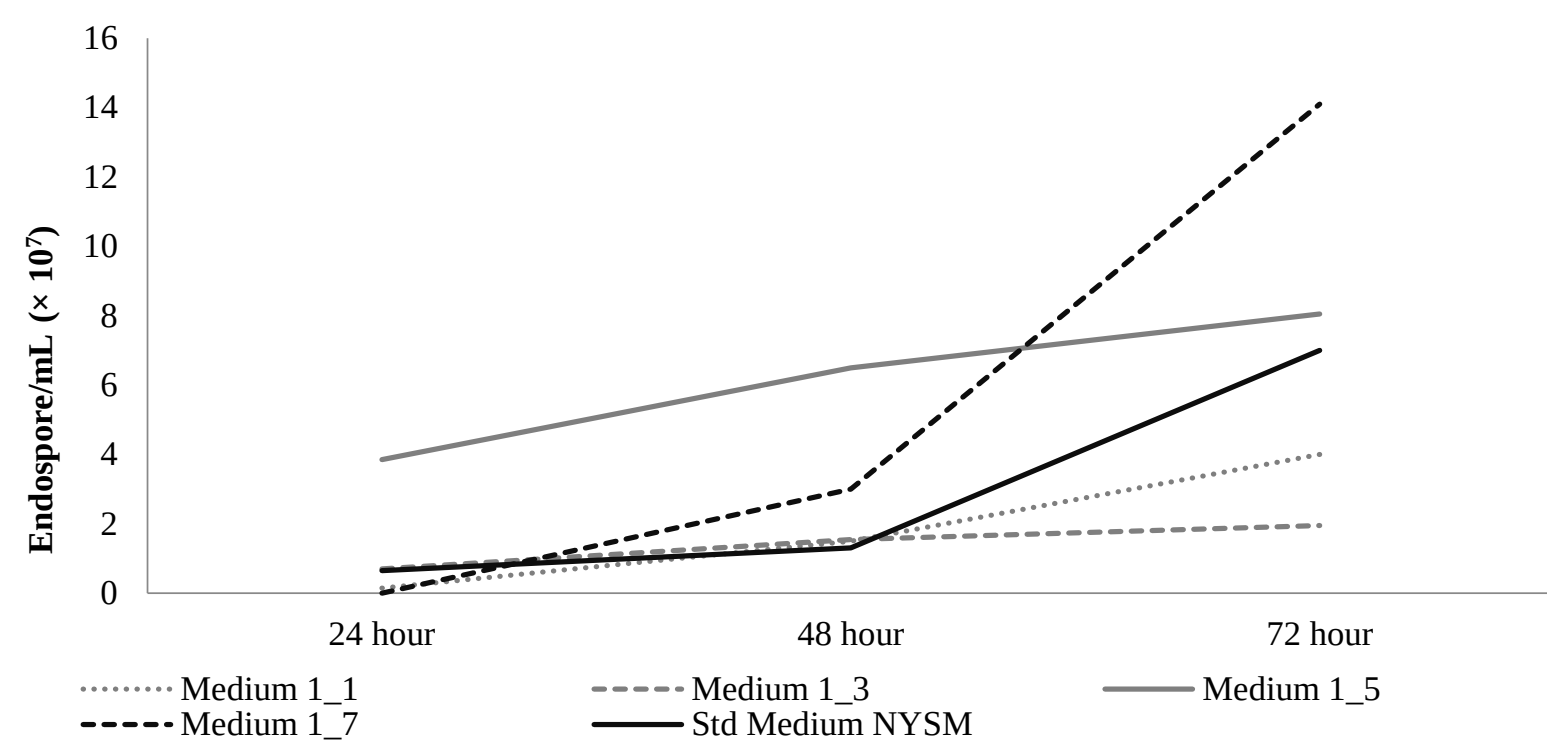

Figure 2. Comparison of endospore concentration among B. thuringiensis grown in 4 combinations of fish flour - palm sugar medium and NYSM standard medium within 72-hour incubation

from all medium applied showed similar growth pattern. Increase in cell concentration was seen from 24-hour incubation until 48-hour incubation. From 48 hours, $B$. thuringiensis cell concentration grown in fish flour - palm sugar natural medium from all ratios decreased rapidly. However, there was no correlation among protein-carbohydrate ratios with final bacterium cell concentration.

Cell concentration decrease after 48-hour incubation presumably was due to consumed carbohydrate in all medium used. This condition becomes a limiting factor to $B$. thuringiensis growth. In addition to the consumed carbohydrate, some acid might be produced from carbohydrate metabolism that decreases $\mathrm{pH}$ of the medium, as low $\mathrm{pH}$ will suppress cell growth and trigger sporulation [12].

\section{Endospore concentration}

Comparison of endospore concentration among $B$. thuringiensis cultured in 4 combinations of fish flour - palm natural sugar medium within 72-hour incubation and NYSM standard medium was presented in Figure 2. All B. thuringiensis grown in fish flour medium (in all ratios) and NYSM standard medium showed significantly 
different endospore concentration $(\mathrm{F}=384.52$, $\mathrm{P}$ $<0.05$ ). The highest endospore concentration in 72 hours was seen on $B$. thuringiensis cultured in fish flour - palm sugar natural medium on $1: 7$ ratio $\left(1.41 \times 10^{8}\right.$ endospore $\left./ \mathrm{mL}\right)$ followed by $1: 5$ ratio medium $\left(8.05 \times 10^{7}\right.$ endospore $\left./ \mathrm{mL}\right)$ and $1: 1$ ratio medium $\left(4.00 \times 10^{7}\right.$ endospore $\left./ \mathrm{mL}\right)$. The lowest was $B$. thuringiensis cultured in NYSM standard medium (7.00 $\times 10^{7}$ endospore $\left./ \mathrm{mL}\right)$, it was lower than $B$. thuringiensis cultured on $1: 1$ ratio.

From this observation, B. thuringiensis cultured in all medium showed increasing endospore concentration trend from the beginning of the incubation. After 48-hour incubation, almost all $B$. thuringiensis endospore concentrations were increased drastically (except those from 1:3 and 1:5 ratio). Once again, there was no correlation among protein-carbohydrate ratios with final bacterium endospore concentration.

The raising on endospore concentration trend is due to lower carbohydrate concentration that consumed by $B$. thuringiensis after 48-hour incubation, as it triggered sporulation process of the bacterium cell. Besides nutrient limitation, some acid might be produced from carbohydrate catabolism [12].

\section{Crystal concentration}

Comparison of crystal concentration among $B$. thuringiensis cultured in 4 combinations of fish flour - palm sugar natural medium within 72-hour incubation was presented in Figure 3.

Observation on toxin crystal synthesis in 72 hour showed significantly different results $(\mathrm{F}=$ 809.95, $\mathrm{P}<0.05$ ). The highest concentration was of $B$. thuringiensis cultured in fish flour - palm sugar natural medium on $1: 1$ ratio $\left(3.00 \times 10^{7}\right.$ crystal $/ \mathrm{mL})$, followed by $1: 3$ ratio $\left(1.90 \times 10^{7}\right.$ crystal $/ \mathrm{mL}), 1: 5$ ratio $\left(1.75 \times 10^{7} \mathrm{crystal} / \mathrm{mL}\right)$ and $1: 7$ ratio $\left(1.45 \times 10^{7}\right.$ crystal $\left./ \mathrm{mL}\right)$. Standard medium NYSM was the lowest of all $\left(6.50 \times 10^{6}\right.$ crystal/mL).

As we could see here, there was correlation among protein-carbohydrate ratios with final bacterium crystal concentration. The lower the carbohydrate content on medium, the higher crystal synthesis could get. There was interesting thing to see here, high concentration of cell and endospore was not necessarily followed or correlated by high toxin crystal production. B. thuringiensis grown on fish flour - palm sugar natural medium on $1: 1$ ratio did not show the highest cell and endospore concentration, yet it showed the highest toxin crystal concentration.

There are some factors affected the production of the bacterial crystal protein:

(1) Carbon source. Glucose is the best carbon source for high $B$. thuringiensis growth and sporulation [13]. The decrease of glucose can trigger sporulation [14].

(2) Nitrogen source. The best source of amino acids allows high growth rate and high sporulation for $B$. thuringiensis. Its absence delays sporulation and low yield in Cry protein production [15].

(3) Carbon : Nitrogen ratio. Higher $\mathrm{C}: \mathrm{N}$ rate glucose causes carbon does not deplete at the end of fermentation, therefore biomass yield decreases.

(4) Oxygen. High aeration rates are important for high spore and toxin formation.

(5) $\mathrm{pH}$. Optimum $\mathrm{pH}$ for $\mathrm{Bt}$ growth is 6.8 - 7.2. If $\mathrm{pH}$ rises to 9.0 Cry protein can be dissolved

(6) Temperature. Optimum temperature for $B$. thuringiensis growth is $28-32^{\circ} \mathrm{C}$. Higher temperatures favours plasmid losses [16].

\section{Toxicity}

Lethal concentration (LC) values of $B$. thuringiensis grown in 4 combinations of fish flour palm sugar natural medium and NYSM standard medium is presented on Figure 4.

From Figure 4, it could be seen that B. thuringiensis grown in fish flour - palm sugar natural medium on $1: 1$ ratio gave the lowest LC values ( $\mathrm{LC}_{50}$ and $\mathrm{LC}_{90}$ ). The $\mathrm{LC}_{50}$ 24-hour value reached $1.98 \times 10^{3} \mathrm{cell} / \mathrm{mL}$, while $\mathrm{LC}_{50} 48$ and 72 hours reached $1.49 \times 10^{3} \mathrm{sel} / \mathrm{mL}$. LC 90 value in 24 hours was $1.35 \times 10^{3} \mathrm{cell} / \mathrm{mL}$, followed by LC 9048 hours $\left(1.58 \times 10^{3} \mathrm{cell} / \mathrm{mL}\right)$ and LC 9048 hours $\left(1.58 \times 10^{3}\right.$ cell $/ \mathrm{mL}$ ). These values were lower than those from NYSM standard medium. The next higher LC value (less toxic) was from $B$. thuringiensis grown in natural medium combination on $1: 3,1: 5$, and $1: 7$ ratios.

Toxicity in B. thuringiensis is mostly causing by its toxin protein synthesized during sporulating stage. Bt synthesize single or multiple types of parasporal crystalline protein ( $\delta$-endotoxins). $\delta$ endotoxins were consisted of crystal (Cry) and/or cytolytic (Cyt). Both areparas poral crystalline protein produced when $B$. thuringiensis enters 


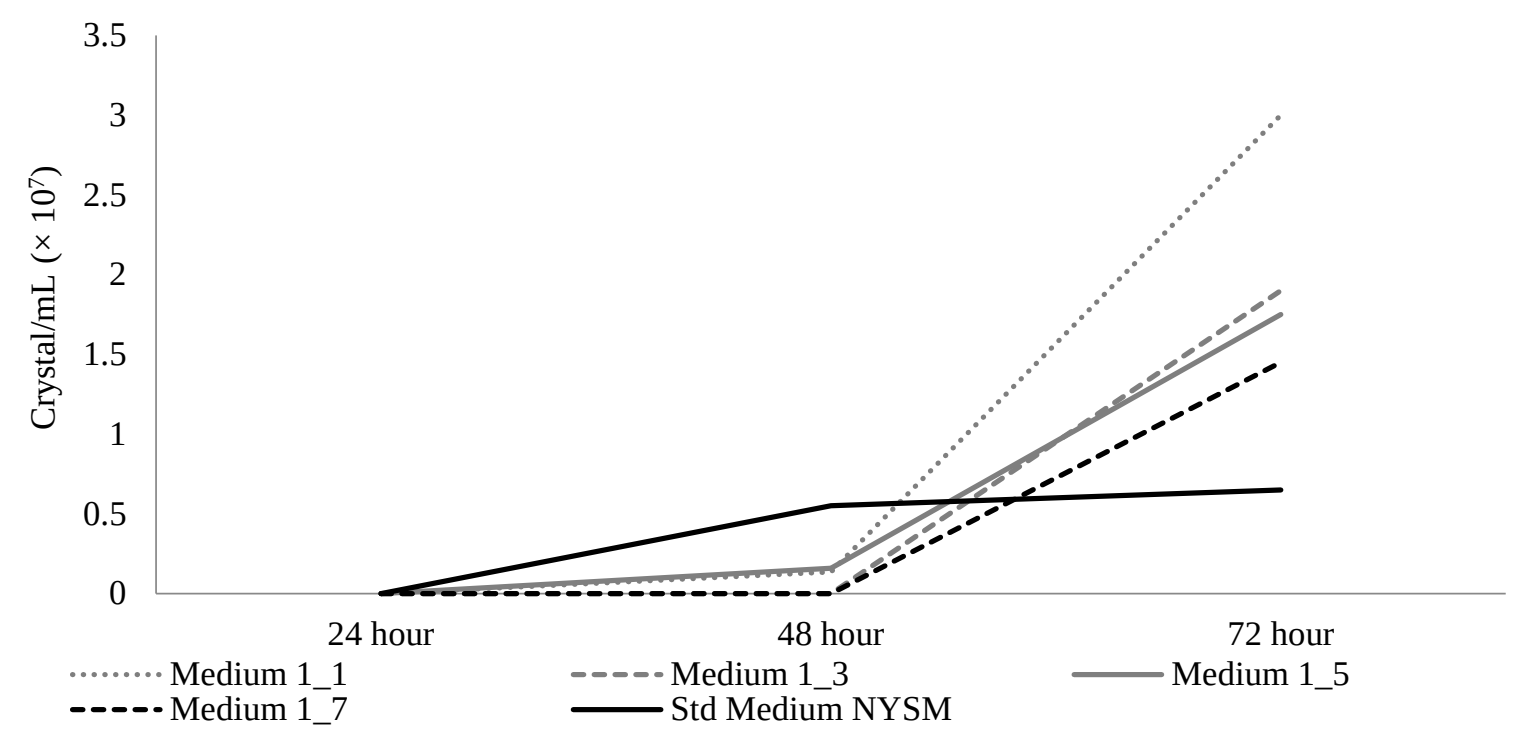

Figure 3. Comparison of crystal concentration among B. thuringiensis grown in 4 combinations of fish flour palm sugar medium and NYSM standard medium within 72-hour incubation

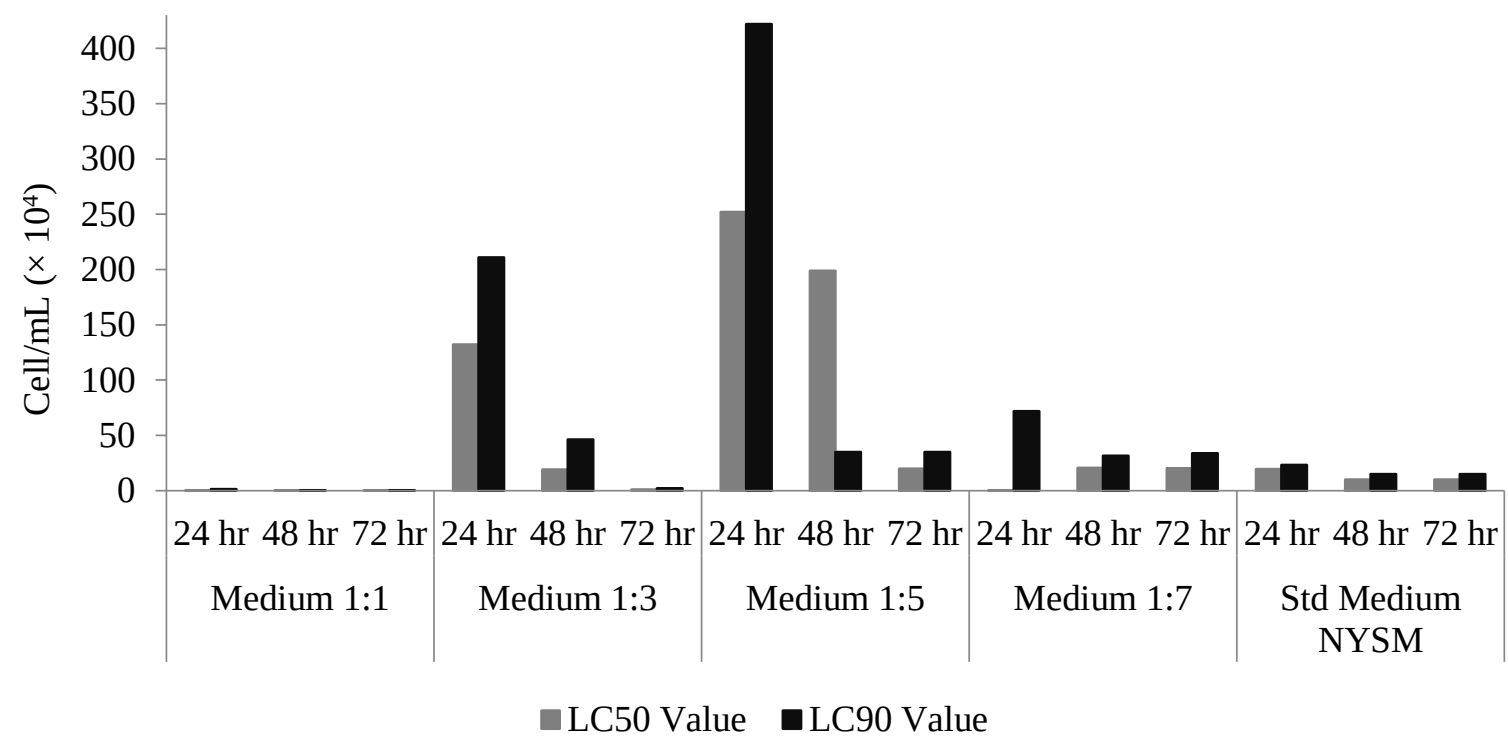

Figure 4. Comparison of LC50 and LC90 values among B. thuringiensis grown in 4 combinations of fish flour - palm sugar medium and NYSM standard medium within 72-hour incubation

sporulation. These toxins are highly specific targeted insects, but harmless to human, vertebrates and plants. These toxins are completely biodegradable [17]. These crystalline proteins are mainly encoded by extra-chromosomal genes located on the plasmids. The parasporal crystalline proteins produced during the stationary phase of B. thuringiensis growth cycle account for $20 \%$ $30 \%$ of the dry weight of the cells of this phase [18]. Expression of most Cry genes (e.g., cry1Aa, cry $2 \mathrm{~A}$, cry $4 \mathrm{~A}$, etc.) are well regulated in the sporulation phase of growth [19].
Larval death occurs several hours after crystal ingested by targeted larvae. Inactive protoxin will solubilize in alkaline condition inside larval midgut. Protoxin will be converted into toxic fragment proteolytically. The fragment will bind to receptor found on apical microvillus membrane of epithelial cell along midgut of targeted larvae. After binding with receptor, the toxins will cause lysis on epithelial cell by the formation of cation-selective channels. This allows free flux of ions and liquids, causing disruption of membrane transport and cell lysis leading to larval death [20, 21]. 


\section{Price comparison}

One problem faced in $B$. thuringiensis-based bio-pesticide production is choosing the appropriate medium to use for fermentation process. It should give maximum cell biomass and cell toxicity, yet very cheap in price [22]. If compared to NYSM standard medium, natural medium based on fish flour and palm sugar offer good potential to be used in a scale-up production scheme.

Fish flour - palm sugar natural medium cost only Rp 37,500 (2.9 US\$) /L. It is 39\% cheaper than NYSM medium (Rp 94,100 or 7.2 US\$ /L). Besides cheaper in price, this natural medium is available in all seasons. In contrast, NYSM medium components should be imported from other countries, makes this medium more expensive and harder to buy or find in Mataram/Indonesia. Therefore, hopefully by using natural medium bacterium-based bio-pesticide production in higher scale will not face any constraint in the future.

\section{Conclusion}

In this study, fish flour-palm sugar medium natural medium can be used to grow $B$. thuringiensis and $1: 1$ ratio medium gave the best toxicity against $A$. aegypti 3rd-instar larvae.

\section{Acknowledgment}

The authors would like to thank West Nusa Tenggara General Hospital for providing research facilities during this study. The authors also thank Biomedika Hospital Mataram for providing funding (Annual Research Fund 2018-2019) to support this study.

\section{References}

1. Dinas Kesehatan Provinsi NTB (2018) Profil kesehatan Provinsi Nusa Tenggara Barat tahun 2017. Mataram, Indonesia, Dinas Kesehatan Provinsi NTB.

2. Bäck AT, Lundkvist $\AA$ (2013) Dengue viruses - an overview. Infection Ecology and Epidemiology 3 (1): 1 - 21. doi: 10.3402/iee.v3i0.19839

3. US EPA (2016) Success in mosquito control: An integrated approach. https://www.epa.gov/mosquitocontrol/success-mosquito-control-integrated-approach.html. Accessed: January 2019.

4. Ibrahim MA, Griko N, Junker M, Bulla LA (2010) Bacillus thuringiensis A genomics and proteomics perspective. Bioengineered Bugs 1 (1): 31 - 50. doi: 10.4161/bbug.1.1.10519.
5. BPS NTB (2019) Provinsi Nusa Tenggara Barat dalam angka 2018. Mataram, Indonesia, BPS NTB.

6. Herfiyanti NF (2018) Isolasi Bacillus thuringiensis entomopatogenik terhadap Culex quinquefasciatus dari beberapa lokasi potensial perindukan nyamuk di Kota Mataram. Bachelor thesis. Universitas Mataram

7. da Silvaa JS, Pinheiroc VCS, Litaiff-Abreub E et al. (2015) Isolation of Bacillus thuringiensis from the state of Amazonas, in Brazil, and screening against Aedes aegypti (Diptera, Culicidae). Revista Brasileira de Entomologia 59 (1): 1 - 6. doi: 10.1016/j.rbe.2015.02.001.

8. El-Bendary MA (2006) Bacillus thuringiensis and Bacillus sphaericus biopesticides production. Journal of Basic Microbiology 46 (2): 158-170. doi: 10.1002/jobm.200510585.

9. McLaughlin RE, Dulmage HT, Ails R et al. (1984) U.S. standard bioassay for the potency assessment of Bacillus thuringiensis Serotype H-14 against mosquito larvae. Bulletin of the Entomological Society of America 30 (1): 26-29. doi: 10.1093/besa/30.1.26.

10. Finney DJ (1971) Probit Analysis. 3rd ed. London, Cambridge University Press.

11. Minitab Inc. (2014) Minitab statistical software V16. Pennsylvania, Minitab Inc.

12. Içgen $Y$, Içgen B, Özcengiz G (2002) Regulation of crystal protein biosynthesis by Bacillus thuringiensis I. Effects of mineral elements and pH. Research in Microbiology 153 (9): 599 - 604. doi: 10.1016/S0923-2508(02)01367-0.

13. Smitha RB, Jisha VN, Pradeep S et al. (2013) Potato flour mediated solid state fermentation for enhanced production of Bttoxin. Journal of Bioscience and Bioengineering 116 (5): 595 601. doi: 10.1016/j.jbiosc.2013.05.008.

14. Dulmage HT (1970) Production of the spore- endotoxin complex by variants of Bacillus thuringiensis in two fermentation media. Journal of Invertebrate Pathology 16 (3): 385 - 389. doi: 10.1016/0022-2011(70)90157-6.

15. Goldberg I, Sneh B, Battae E, Klein D (1980) Optimization of a medium for a high production of spore-crystal preparation of Bacillus thuringiensis effective against Egyptian cotton leaf worm Spodoptera littorallis. Biotechnology Letters 2 (10): 419 - 426. doi: 10.1007/BF00162348.

16. Rowe GE, Margaritis AM (1087) Rowe \& Margaritis 1987.txt. CRC Critical Reviews in Biotechnology 6 (4): 87 - 127.

17. Bravo A, Gill SS, Soberón M (2013) Mode of action of Bacillus thuringiensis Cry and Cyt Toxins and their potential for insect control. Toxicon 49 (4): 423-435. doi: 10.1016/j.toxicon.2006.11.022.

18. Agaisse H, Lereclus D (1995) How does Bacillus thuringiensis produce so much insecticidal crystal protein? Journal of Bacteriology 177 (21): 6027 - 6032. doi: 10.1128/jb.177.21.60276032.1995 
BF Suryadi, HA Hidayat, G Tresnani, 2019 / The Use of Fish Flour and Palm Sugar Medium to Grow Mataram Indigenous Isolate

19. Dowell DGM, Mann NH (1991) Characterization and sequence analysis of a small plasmid from Bacillus thuringiensis var kurstaki Strain HD1-DIPEL. Plasmid 5 (2): 113 - 120. doi: 10.1016/0147-619X(91)90022-O.

20. Aronson A, Geng C, Wu L (1999) Aggregation of Bacillus thuringiensis Cry1A toxins upon binding to target insect larval midgut vesicles. Applied and Environmental Microbiology 65 (6): $2503-2507$.
21. Höfte H, Whiteley HR (1989) Insecticidal crystal proteins of Bacillus thuringiensis. Microbiological Reviews 53 (2): 242 255.

22. Poopathi S, Tyagi BK (2004) Mosquitocidal toxins of spore forming bacteria: Recent advancement. African Journal of Biotechnology 3 (12): 643 - 650 . 
This page is intentionally left blank. 